JMKSP (Jurnal Manajemen, Kepemimpinan, dan Supervisi Pendidikan)

Volume 7 Issue 1 (2022) Page 283-300

ISSN 2614-8021 (Online) 2548-7094 (Print)

\title{
The Effect of Group Investigation Learning Model on Students' Critical Thinking Ability in Pancasila Education Courses
}

\author{
Ramanata Disurya $^{1}$, Syukri Hamzah ${ }^{2}$ \\ ${ }^{1}$ Universitas PGRI Palembang, ${ }^{2}$ Universitas Bengkulu \\ Corresponding Author E-mail: ramanatadisurya24@gmail.com \\ Received 8 September 2021; Revised 21 December 2021; \\ Accepted 31 January 2022
}

\begin{abstract}
The purpose of this study is to see how the group investigation learning model affects students' critical thinking skills in Pancasila education courses. A quasi-experimental approach with a nonequivalent control group was adopted for the investigation. The demographic utilized is all PGSD Study Program students. The control class has 35 pupils, whereas the experimental class has 33 people. The experimental class employs the group investigation learning model, whereas the control group employs a traditional learning model. In this study, the average pretest value of the experimental class is 35.4 , whereas the control class's pretest value is 35.8. The average value of critical thinking abilities on the posttest differed between the two learning regimens. The group investigation learning approach has a substantial impact on the critical thinking abilities of PGRI University Palembang students enrolled in the Pancasila Education course.
\end{abstract}

Keyword: Group, Investigation, Critical Thinking

\section{Introduction}

Education is a sense of awareness and duty to become a whole human being; education is now inextricably linked to the human lifestyle. Someone who is uneducated will not be able to keep up with the trends in the twenty-first century, especially with the Industrial Revolution 4.0. This research is built on earlier research to reinforce it (Mushoddik et al., 2016) where the findings of a 
study of students' critical thinking skills at MAN 6 Jakarta were assessed using essay questions The findings of the pretest and posttest scores are used to calculate critical thinking ability test scores (gainscore). The Group Investigation learning paradigm had an influence on students' critical thinking skills, according to the findings. The data analysis shows that the value of $\mathrm{t}=3.432$ and the two-tailed significance of 0.01 are less than $=0.05$. The average critical thinking ability of the experimental class pupils is 25.64 , which is greater than the control class's 19.88 .

Next (Nuryatin, 2015) the findings revealed that there were differences in students' critical thinking skills in the experimental and control classes in the initial and final measurements, no differences in students' critical thinking skills in the final measurement between the experimental and control classes, and differences in the improvement of critical thinking skills between students who studied with the Group Investigation type of cooperative learning $\mathrm{m}$. This suggests that the Group Investigation kind of cooperative learning paradigm improves students' critical thinking skills. Active learning can provide direct experience to build their own knowledge, which includes the formation of concepts, applications, analysis, and assessing the information gathered in problem solving, so that the development of critical thinking skills will be very easy to develop from the lowest to the highest stage.

Then the research (Maharani, 2017) based on the findings of this study, it was determined that the group investigation learning approach had an influence on students' trigonometry learning accomplishment. Students' trigonometry learning accomplishment utilizing the group exploration model outperforms student learning achievement using the lecture/conventional technique, and (Mirnawati, 2017 ) it is possible to deduce that with the high t-count value of 5.564, it has a significant level of 0.000 , which is still far below the value of $=0.05$. As a result, this study was successful in rejecting the 5\% significant threshold. It may be concluded that the experimental group's creativity or creative thinking capacity is greater than the control group's. The cooperative learning approach of group exploration has a good influence on students' creativity or creative thinking capacity.

Ngalimun (2012) according to the definition, a learning model is a design or pattern that is utilized as a learning aid in the classroom. This indicates that the learning model is a design that lecturers employ in class to educate. The group investigation type cooperative learning model is one of the learning models that may be used in the classroom. Because students are involved in the planning of 
both the topics examined and the learning process, group research is a complicated cooperative learning approach (Sumarmi, 2012). According to this explanation, the group investigation model is a learning model that emphasizes and focuses on group cooperation and requires each member of the group to be able to prioritize the role of students in finding and managing information to become the understanding needed by students as well as think critically about a problem that he encountered. Critical thinking is a student's capacity to make accurate conclusions based on logical rules and to demonstrate that the findings are right in light of previously acquired knowledge (Kusmanto, 2014). During learning, lecturers can also develop critical thinking abilities. Students' activeness and critical attitude might have a good impact on learning activities.

The group investigation learning model is a learning model whose grammar meets the critical thinking ability markers. Critical thinking talents in learning must be improved right now. Many studies on the group investigation learning paradigm have been undertaken. One of them is a research paper (Hartono \& Deni Puji, 2014), and the study's findings indicate that the group investigation learning model impacts learning outcomes. Those who study in a group exploration model learn more than students who study in a lecture format. According to research (Juniartina, 2015), employing the group investigation learning model is superior to using the traditional learning model. According to research (Sugiarti, 2012), the group investigation learning approach influences student progress and creative thinking abilities.

According to the description above, the group investigation learning paradigm allows students to be more active in the learning process and promotes critical thinking. This allows kids' conceptual comprehension and critical thinking abilities to grow. As a result, researchers wish to investigate the impact of the group investigation learning model on students' critical thinking abilities.

\title{
2. Methods
}

The method used in this study is a quasi-experimental research design with nonequivalent control group design. The research design can be seen in the following table.

\author{
Table 1. The Research Design \\ $\begin{array}{lll}\mathrm{O}_{1} & \mathrm{X} & \mathrm{O}_{2}\end{array}$ \\ $\mathrm{O}_{3} \quad-\quad-\mathrm{O}_{4}$ \\ (Sugiyono, 2017)
}


The study was carried out at the PGSD Study Program, PGRI University Palembang, during the Odd Semester 2021/2022. Semester 1L and 1N were the topics of this research. The experimental class has 33 pupils, whereas the control class has 35 people. This study's instrument is a critical thinking ability exam, and the test questions are in the form of descriptions.

\section{Results and Discussion}

The research data was gathered in the form of student learning outcomes score data. After the application of the Group Investigation learning model in Pancasila education topics at the PGSD Study Program, PGRI University Palembang, the first test before treatment (pretest) and the final bag after treatment (posttest) The content delivered by the researcher throughout three meetings is included in the test. The tests offered to students are the pretest given before students receive learning so that researchers can determine the students' beginning skills, the test given at each meeting, and the final test given after students acquire learning.

The data utilized in this study is the critical thinking skills test result score of pupils. In this study, the average pretest value of the experimental class is 35.4, whereas the control class's pretest value is 35.8 . The average value of critical thinking abilities on the posttest differed between the two learning regimens. The posttest average of critical thinking skills was 80.7 in group inquiry learning and 69.87 in conventional model learning.

\section{Critical Thinking Ability of Control Class Students}

The control class was used for the pretest to collect data on students' critical thinking skills. The exam for the control group is the same as the test for the experimental group, and it consists of ten essay questions. In the control class, the pretest data of students' critical thinking skills yielded the lowest score of 20 and the maximum score of 60 . The findings from the pretest of critical thinking abilities of experimental class students are shown in the table below for clarity:

Table 2. Pretest Data of Critical Thinking Ability Control class students

\begin{tabular}{cccc}
\hline No & Interval & Frequency & Percentage \\
\hline 1 & $20-28$ & 7 & $20 \%$ \\
2 & $29-37$ & 14 & $40 \%$ \\
3 & $38-46$ & 13 & $37.14 \%$ \\
4 & $47-55$ & 0 & $0 \%$ \\
5 & $56-64$ & 1 & $2.86 \%$ \\
& Total & 35 & $100 \%$ \\
\hline
\end{tabular}


The control class pretest yielded an average score of 35.8. According to the table above, there are 5 interval courses, with an 8-minute pause between each session. It is clear that the highest percentage is $40 \%$ in the interval value of 29-37. While the least proportion is $0 \%$, there is a range of 47-50. Based on the calculation findings, an average of 35.8 was achieved, with the maximum value (Xmax) being 60 and the lowest value being 20 (Xmin).

The following is a recapitulation of the average value of each indication of critical thinking ability to determine the accomplishment of students' critical thinking abilities in the experimental class pretest on each indicator. This information was collected by an examination of the student's test scores on the critical thinking ability test questions. In the table below, you can see the average value of the pretest indication of the control class's critical thinking ability.

\begin{tabular}{llll} 
Table 3. The Control Class's Average Critical Thinking Indicator Score \\
\hline Critical Thinking Indicator & Ideal Score & Average & Percentage (\%) \\
\hline Elementary Clarification & 12 & 3.8 & $31 \%$ \\
Basic suport & 8 & 1.1 & $13 \%$ \\
Inference & 4 & 3.0 & $75 \%$ \\
Advanced clarification & 8 & 2.7 & $33 \%$ \\
Strategy and Tactics & 8 & 2.5 & $31 \%$ \\
\hline
\end{tabular}

This can be observed in the acquisition of the inference percentage, which achieved the maximum percentage of $75 \%$, while the basic support indicator obtained the lowest percentage of 13\%. In the control group, a posttest was administered to collect data on students' critical thinking abilities. The exam for the control group is the same as the test for the experimental group, and it consists of ten essay questions. In the control group, post-test data on students' critical thinking skills showed that the lowest score was 55 and the best score was 85 . The data from the post-test results for the experimental class students' critical thinking skills are shown in the table below for clarity:

\begin{tabular}{|c|c|c|c|}
\hline No & Interval & Frequency & Percentage \\
\hline 1 & $55-61$ & 8 & $22.86 \%$ \\
\hline 2 & $62-69$ & 7 & $20 \%$ \\
\hline 3 & $70-76$ & 11 & $31.43 \%$ \\
\hline 4 & $77-83$ & 7 & $20 \%$ \\
\hline 5 & $84-90$ & 2 & $5.71 \%$ \\
\hline & Total & 35 & $100 \%$ \\
\hline
\end{tabular}


The average value in the control class pretest was 69.87. The table above shows that the number of interval classes is five, with a length of six for each class interval. It can be observed that the highest percentage is 31.43 percent in the range 70-76. While the lowest proportion is 5.71 percent, there are intervals ranging from 85 to 90 percent. Based on the calculated findings, the average is 69.87, the maximum value (Xmax) is 85 , and the minimum value is 55 (Xmin).

The following is a recapitulation of the average value of each indication of critical thinking ability to determine the accomplishment of students' critical thinking abilities in the control class posttest on each indicator. This information was collected by an examination of the student's test scores on the critical thinking ability test questions. In the table below, you can see the average value of the pretest indication of the control class's critical thinking ability.

\section{Table 5. Posttest Average Score Critical Thinking Indicator Control Class}

\begin{tabular}{llll}
\hline Critical thinking indicator & Ideal Score & Average & Percentage (\%) \\
\hline Elementary Clarification & 12 & 7,8 & $65 \%$ \\
Basic suport & 8 & 2,6 & $32 \%$ \\
Inference & 4 & 5,8 & $72 \%$ \\
Advanced clarification & 8 & 5,4 & $67 \%$ \\
Strategy and Tactics & 8 & 5,4 & $67 \%$ \\
\hline
\end{tabular}

This can be observed in the acquisition of the inference percentage, which achieved the greatest percentage of 72 percent, while the basic support indication earned the lowest percentage of 32 percent.

\section{Experimental Class Students' Critical Thinking Ability}

In the experimental class, a pretest was administered to collect data on students' critical thinking abilities. The experimental class is given a test consisting of ten descriptive questions. In the control class, the pretest data of students' critical thinking skills yielded the lowest score of 20 and the maximum score of 60. The findings from the pretest of critical thinking abilities of experimental class students are shown in the table below for clarity: 


\section{Table 6. Pretest Data on Critical Thinking Ability of}

Experimental Class Students

\begin{tabular}{cccc}
\hline No & Interval & Frequency & Percentage \\
\hline 1 & $25-32$ & 7 & $21.21 \%$ \\
2 & $33-40$ & 10 & $30.31 \%$ \\
3 & $41-48$ & 14 & $42.42 \%$ \\
4 & $49-56$ & 1 & $3.03 \%$ \\
5 & $57-64$ & 1 & $3.03 \%$ \\
& Total & 33 & $100 \%$ \\
\hline
\end{tabular}

In the experimental class pretest, an average value of 35.4 was achieved; the table above shows that the number of interval classes is 5 , with a length of 7 for each class interval. In the 41-48 value bracket, the highest percentage is 42.42 percent. While the smallest percentage is 3.03 percent, there are intervals of 49-56 and 57-64. Based on the calculation findings, an average of 35.4 was achieved, with the maximum value (Xmax) being 60 and the lowest value being 20 (Xmin).

The following is a recapitulation of the average value of each indication of critical thinking ability to determine the accomplishment of students' critical thinking abilities in the experimental class pretest on each indicator. This information was collected by an examination of the student's test scores on the critical thinking ability test questions. In the table below, you can see the average value of the pretest predictor of the experimental class's critical thinking ability:

Table 7. The Average Pretest Value of the Experimental Class Critical Thinking Indicator

\begin{tabular}{llll}
\hline Critical thinking indicator & Ideal Score & Average & Percentage (\%) \\
\hline Elementary Clarification & 12 & 1.7 & $14 \%$ \\
Basic suport & 8 & 1.0 & $25 \%$ \\
Inference & 4 & 3.3 & $41 \%$ \\
Advanced clarification & 8 & 2.2 & $27 \%$ \\
Strategy and Tactics & 8 & 4.7 & $58 \%$ \\
\hline
\end{tabular}

This can be observed in the acquisition of the strategy and tactics percentage, which obtains the greatest percentage of 58 percent, while the elementary clarification indication obtains the lowest percentage of 14 percent. In the experimental class, a posttest was administered to collect data on students' critical thinking abilities. The experimental class is given a test consisting of ten descriptive questions. In the control group, posttest data on students' critical thinking skills yielded the lowest score of 60 and the highest score of 100. The 
posttest statistics on critical thinking abilities of experimental class students are shown in the table below for clarity:

Table 8. Posttest Data of Experimental Class

Students' Critical Thinking Ability

\begin{tabular}{cccc}
\hline No & Interval & Frequency & Percentage \\
\hline 1 & $60-69$ & 1 & $3.0 \%$ \\
2 & $70-78$ & 11 & $33.5 \%$ \\
3 & $79-87$ & 12 & $36.5 \%$ \\
4 & $88-96$ & 8 & $24.2 \%$ \\
5 & $97-100$ & 1 & $3.0 \%$ \\
& Total & 33 & $100 \%$ \\
\hline
\end{tabular}

The average result in the posttest experimental class was 80.7. From the table above, it can be seen that the number of class intervals is 5 and the length of each class interval is 8 . It can be observed that the highest percentage is 36.5 percent at intervals of 70-78, while the lowest percentage is 3.0 percent at intervals of 60-69 and 97-100. The average value is 80.7 , the greatest value (Xmax) is 100 , and the lowest value is 60, according to the calculation findings (Xmin). The following is a recapitulation of the average value of each indication of critical thinking ability to determine the accomplishment of students' critical thinking abilities in the posttest experimental class on each indicator. This information was collected by an examination of the student's test scores on the critical thinking ability test questions. The average posttest value of the experimental class critical thinking ability indicator is shown in the table below.

Table 9. The Average Score of the Posttest Indicators of Critical Thinking Experiment Class

\begin{tabular}{llll}
\hline Critical thinking indicator & Ideal Score & Average & Percentage (\%) \\
\hline Elementary Clarification & 12 & 3,0 & $25 \%$ \\
Basic suport & 8 & 3,1 & $77 \%$ \\
Inference & 4 & 6,9 & $86 \%$ \\
Advanced clarification & 8 & 6,0 & $75 \%$ \\
Strategy and Tactics & 8 & 4,6 & $80 \%$ \\
\hline
\end{tabular}

This can be observed in the acquisition of the inference percentage, which is 86 percent, while the elementary clarification indicator obtains the lowest proportion, which is 25 percent. The test value data provided will be examined in order to prove the hypothesis and reach a conclusion. The N-Gain Test, simple linear regression test, and t-test were used in this study's data analysis to test the 
hypothesis proposed in this study, namely the improvement of critical thinking skills following the implementation of the Group Investigation learning model at the University of PGRI Palembang, and the t-test was used to test the hypothesis. The Group Investigation learning paradigm has an influence on improving students' critical thinking abilities.

\section{Testing N-gain}

The data derived from the start and final test results in the form of scores were provided to assess the average growth in students' critical thinking abilities after being taught the Group Investigation learning paradigm. Normalized gain can be used to calculate the data. The calculation results are then analyzed using the gain categorization once they have been achieved. The appendix contains a table of calculation results for the students' initial and final examinations. The table below shows the results of the analysis of increasing students' critical thinking abilities based on the gain classification:

Table 10. Results of Data Analysis of Pre-Test and Post-Test

\begin{tabular}{ccccccc}
\hline & \multicolumn{3}{c}{ Experiment } & \multicolumn{3}{c}{ Control } \\
\cline { 3 - 7 }$\sum$ & Pretest & Postest & N-gain & Pretest & Postest & N-gain \\
$X$ & 1308 & 2669 & 22,57 & 1188 & 2434 & 18,58 \\
$X$ & 35,40 & 80,70 & 0,69 & 35,80 & 69,87 & 0,54 \\
\hline
\end{tabular}

Based on the data presented above, it is possible to conclude that the difference between the posttest and pretest scores equals the $\mathrm{N}$-gain number. The average pretest score for the experimental class is 35.40 , and the average posttest score is 80.70 , with an average $\mathrm{N}$-gain of 0.69 , placing it in the middle range. The average pretest score for the control group is 35.80, while the average post-test score is 69.87 , with an average $\mathrm{N}$-gain of 0.54 and is classified as moderate. Based on the reasoning above, it is possible to deduce that these two classes have different critical thinking skills.

\section{Normality Testing}

Normality testing is used to determine whether or not the sample under examination is normally distributed. The SPSS 22 program is used in this study for the normally test. The data is considered to be normal if the value of Sig (p) is 
more than or equal to 0.05 , and abnormal if the value of Sig (p) is less than or equal to 0.05 . The results of the normally test are shown in the table below.

Table 11. Normality Test Results of Students' Critical Thinking Ability Experiment class and Control class.

\begin{tabular}{clcccc}
\hline \multirow{2}{*}{ Result } & Learning & Statistic & Df & Sig. & $\mathrm{H}_{\mathrm{o}}$ \\
\hline \multirow{2}{*}{ Pretest } & Experiment & 0,143 & 33 & 0,094 & \\
& Control & 0,136 & 35 & 0,114 & Accepted \\
\multirow{2}{*}{ Postest } & Experiment & 0,128 & 33 & 0,199 & \\
& Control & 0,142 & 35 & 0,081 & \\
\hline
\end{tabular}

The significant value for the experimental class on the pretest results is 0.094 with a value of $=0.05$ based on the table of normality test results in the table above. Because the significant value is $0.094>0.05$, the data may be deemed normally distributed. Similarly, the experimental class post-test findings yielded a significant value of 0.199 . If the Sig value is more than 0.05 , the data shows that the experimental class posttest data can be regularly distributed. The data was deemed to be normally distributed when the control class in the pretest received a significant value of 0.114 because the significant value was $0.114>0.05$. While the posttest results on students' critical thinking abilities in the control group was significant at 0.081 . The sig value of $0.081>0.05$ suggests that the postets data from the control class are regularly distributed. As a result, the data from the two classes demonstrates that the data is regularly distributed and fits the conditions for analysis.

\section{Homogeneity Testing}

Data homogeneity testing is used to demonstrate the comparability of the variance of the groups that comprise the sample, i.e., groups chosen from the same population. The SPSS 22 software was used to assess the homogeneity of the data in this investigation. Decision making at a considerable level of 5\% $(\alpha=0,05)$ :

- If the score $\mathrm{Sig} \geq 0,05$ then $\mathrm{H}_{0}$ accepted, it means that the sample variance is said to be homogeneous.

- If the score $\mathrm{Sig}<0,05$ then $\mathrm{H}_{0}$ rejected, it means that the sample variance is declared to be non-homogeneous.

The results of the homogeneity test can be seen in the following table 


\section{Table 12. Results of Homogeneity Test of Critical Thinking Ability of Experimental Class and Control Class Students}

\begin{tabular}{lccccc}
\hline & Statistik Levene & df1 & df2 & Sig. & Ho $_{\mathbf{0}}$ \\
\hline Pretest & 0,078 & 1 & 66 & 0,783 & \multirow{2}{*}{ Accepted } \\
Postest & 0,428 & 1 & 66 & 0,515 & \\
\hline
\end{tabular}

The significant value for the pretest results achieved a significant value of 0.783 , according to the table above. The sig value of $0.783>0.05$ suggests that the pretest is homogenous in the experimental and control classes. While calculating the posttest results, a sig value of 0.515 was achieved. The sig value of 0.515 is more than 0.05 , indicating that the posttest results in the experimental and control groups are homogenous. The data from the student's critical thinking ability test results are regularly distributed and homogenous, according to the normality test table and the homogeneity table.

\section{Hypothesis Testing}

In this study, the hypothesis is "There is an impact of the group investigation learning model on critical thinking abilities of PGRI Palembang University students." To prove the hypothesis, as well as to obtain the results and conclusions of the analysis, the following methods were used:

\section{Simple Linear Regression Test}

This basic linear regression test is designed to determine whether the $\mathrm{X}$ variable has an influence on the $\mathrm{Y}$ variable, implying that the effect seen may be generalized to the population using the linear regression coefficient formula. The SPSS Version 22 application was used to perform simple linear regression analysis in this investigation. The regression test is shown in the table below:

Table 13. Simple Linear Regression Test Calculation Results Coefficients $^{\mathrm{a}}$

\begin{tabular}{|c|c|c|c|c|c|c|}
\hline \multirow[b]{2}{*}{ Model } & & \multicolumn{2}{|c|}{ Unstandardized Coefficients } & $\begin{array}{l}\text { Standardized } \\
\text { Coefficients }\end{array}$ & \multirow[b]{2}{*}{$\mathrm{T}$} & \multirow[b]{2}{*}{ Sig. } \\
\hline & & B & Std. Error & Beta & & \\
\hline 1 & (Constant) & 2,415 & ,374 & & 7,450 & ,000 \\
\hline & GI &,- 038 & ,005 & ,563 & 3,4021 &, 000 \\
\hline
\end{tabular}

a. Dependent Variable: critical thinking skills 
The sig value was calculated using the results of a simple linear regression test performed using SPSS version 22. 0.000, and the value of "t" is 3.4021. In the coefficient table, the acquisition of a basic linear regression test. The hypothesis "There is an Influence of Group Investigation Learning Model on Students' Critical Thinking Ability" was accepted after obtaining a significant value of 0.00 0.05 . The results of the simple regression coefficients reveal that the constant coefficient value is 2.415 , and the coefficient of the independent variable (X) is 0.038 , as shown in the table above. As a result, the regression equation $\mathrm{Y}=$ $2.415+0.038 \mathrm{X}$ is derived. Furthermore, the positive value $(0.038)$ is the regression coefficient of the variable $X$ (group investigation learning model), indicating that the relationship between the $\mathrm{Y}$ variable (critical thinking ability) is unidirectional, with every increase in the unit variable $X$ (group investigation learning model) causing an increase in critical thinking skills. 0.038 for the student.

\section{T-Test}

Following the basic Linear Regression Test, the Independent Sample t-test was used to determine whether or not the group investigation learning model had a significant influence on the critical thinking skills of PGRI Palembang University students. This research compared the untreated control group to the treated experimental group. The t-test was used to compare the means of two groups that were unrelated to one another. The average posttest scores of the two groups sampled in this study, the experimental group and the control group, were compared.

The hypotheses in this study are:

$H_{o}$ : The group inquiry learning approach has no substantial effect on the critical thinking skills of PGRI Palembang University students.

$H_{a}$ : The group inquiry learning style has a substantial impact on the critical thinking abilities of PGRI Palembang University students.

The researcher utilized statistical testing to determine the validity of the hypothesis. The t-test, also known as the Independent Sample T-test, was employed for two independent samples. With the criterion of rejecting Ho if the value of Sig.(2-tailed) is less than 0.05 and accepting Ho if the value of Sig.(2tailed) is more than 0.05 , or accepting Ho if the value of $t$-count is less than t-table and rejecting Ho if the value of $t$-count is greater than $t$-table. The $t$ test results from SPSS 22 are shown below: 


\section{Table 14. The results of the Hypothesis Test of Critical Thinking Ability Independent Samples Test}

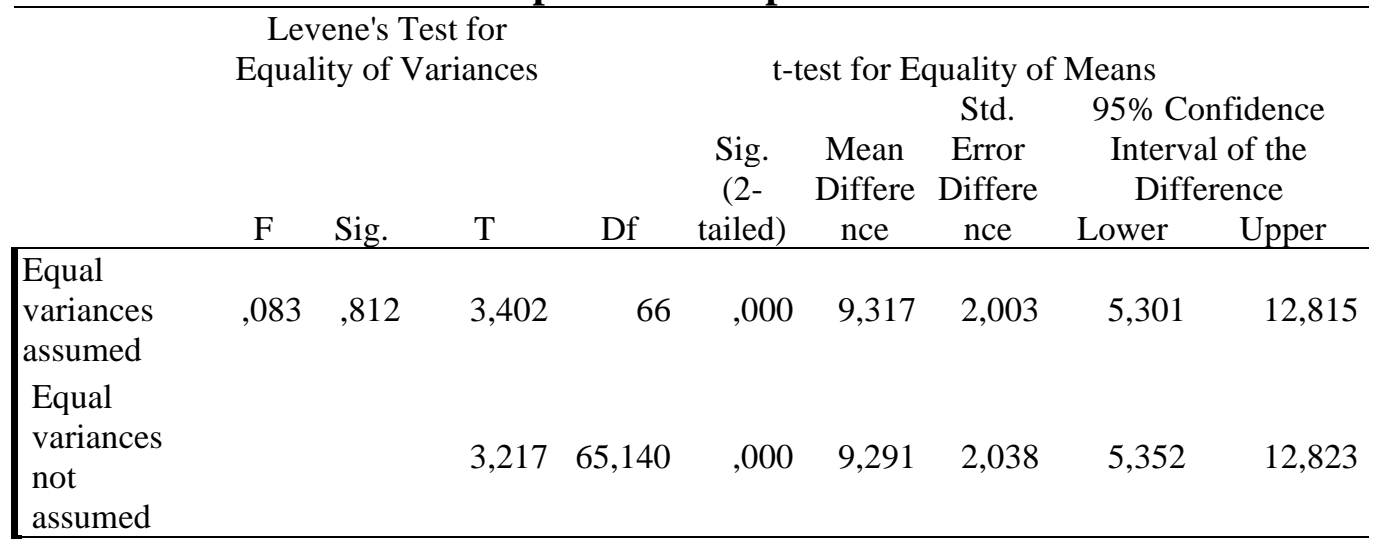

Based on the findings of the t-test computation above, it is determined that $\mathrm{t}$ is larger than 0.05, implying that $\mathrm{HO}$ is accepted and $\mathrm{Ha}$ is rejected. The researcher utilized statistical testing to determine the validity of the hypothesis. The t-test, also known as the Independent Sample T-test, was employed for two independent samples. With the criterion of rejecting Ho if the value of Sig.(2-tailed) is less than 0.05 and accepting Ho if the value of Sig.(2-tailed) is more than 0.05, or accepting Ho if the value of t-count is less than t-table and rejecting Ho if the value of t-count is greater than t-table. The results of the t-test using SPSS 22 show that $\mathrm{t}$-count $3,402>$ t-table 0.05 . As a result, it is possible to conclude that there is a substantial difference in the group inquiry learning model on the critical thinking abilities of PGRI University students enrolled in the Pancasila Education course.

The findings revealed that employing the group investigation learning approach had an influence on students' critical thinking skills. This is due to the fact that the group inquiry learning process stresses active student engagement in subject selection, research, analysis, and presentation or reporting of results. This investigative group learning technique can also promote student involvement in finding knowledge on their own by utilizing various accessible sources such as learning books and the internet. Reading a variety of existing references helps boost students' insight and knowledge, therefore encouraging and developing students' critical thinking abilities.

Thus, the difference between the control group, which utilizes the conventional learning model, and the experimental group, which employs the 
group investigation learning model, is related to the treatment used. This suggests that the difference in students' critical thinking abilities is the result of the therapy provided by the group investigation learning approach. The stages of the group investigation learning model have an impact on students' critical thinking abilities. The group investigation learning model has six stages. The group investigation learning model's six steps can help you enhance your critical thinking abilities.

First, students are advised to discover subtopics that they are interested in for further inquiry during the phase of determining the topic. According to Suprijono (2009), the group investigation learning model is a learning paradigm in which each group performs an inquiry on the topic or problem of their choice. The second step is inquiry planning, during which students are expected to devise a strategy for their group activities.

The third stage consists of investigative tasks, which require students to think about gathering information, interpreting data, and assessing information. The fourth step is report preparation, in which students and groups decide what they will report and how they will present their findings. At this stage, the group discusses comparing members' ideas in order to find the greatest ideas in the group. The fifth stage is giving the final report; this syntax helps students discover how to communicate the results effectively in front of other groups. In addition, the final implementation of the experimental and control class learning was performed posttest. Following therapy, posted is used to assess critical thinking abilities. The results of the pretest and posttest were compared to ascertain the difference in scores and then the data was examined. To put the hypothesis to the test, use a basic linear regression test and a t test. The t-test was calculated using the SPSS version 22 application. The threshold of significance utilized was 0.05 . The $t-$ test computation yields a significance (2-tailed) of 0.000 . H0 is rejected since the significance value (probability) is less than 0.05 , therefore that $\mathrm{Ha}$ is accepted. As a result, it is possible to conclude that there is a substantial difference in the group inquiry learning model on critical thinking abilities of PGRI University students enrolled in the Pancasila Education course.

This is consistent with the belief (Syayidah, 2016) that one of the keys for increasing comprehension is the activity of expressing ideas and delivering replies. According to Slavin (2010), group discussion activities and sharing perspectives can foster student growth and cognitive development. The sixth step is assessment, in which students provide feedback to one another on the topic, the tasks they 
completed, and the usefulness of their experiences in investigative activities. The act of examining, reasoning, and selecting a pattern of study that can provide the best solution, according to (Feldman. 2016), is the scope of critical thinking.

The group investigation learning methodology used in the experimental class engages students actively in the learning process by allowing them to conduct autonomous investigations on the lecturer's material subjects. During the learning process, each member of the group collaborates to undertake an investigation. Students are divided into groups to examine a topic in group investigation learning. The students next assess the findings of the studies, which might teach them to think critically. According to Nurhayati (2014), critical thinking is the process of examining thoughts or concepts in a more precise direction, clearly differentiating them, selecting, recognizing, reviewing, and developing them in a more ideal way. The group investigation learning technique is more active in directing students to discover knowledge on themes chosen by the lecturer on their own. This viewpoint is confirmed by research (Wuryani, 2017), which shows that studying with the group investigation approach can increase student engagement in learning.

This research is supported by the findings of a previous study (Siti Bahriyah, 2017), which found that the group inquiry (GI) learning model has an impact on the capacity to think critically in mathematics. Following that study, (Anggi, 2012) discovered that group investigation learning had an influence on students' critical thinking.

\section{Conclusion}

Based on the findings of the data analysis and discussion in this study, it is possible to infer that the group inquiry learning model improves the critical thinking abilities of students enrolled in the PGSD study program at Pancasila Education. The experimental class outperforms the control class in terms of score. This is due to a number of advantages of the group investigation model, the investigation's execution, and the students' active participation in debates and presentations.

\section{References}

Anggi, I. (2012). Penerapan Model Pembelajaran Kooperatif Tipe Group Investigation (GI) Terhadap Kemampuan Berpikir Kritis Siswa Pada Materi Pembelajaran Keanekaragaman Hayati (Studi Kuasi Eksperiment pada Siswa Kelas X SMA Negeri 1 Natar 2011/2012 [The Application of the Group Investigation (GI) Cooperative 
Learning Model on Students' Critical Thinking Ability in Biological Diversity Learning Materials (Quasi Experimental Study on Class X Students of SMA Negeri 1 Natar 2011/2012]. Fakultas Keguruan dan Ilmu Pendidikan. Universitas Lampung. Bahriyah, S. (2017). Pengaruh Model Pembelajaran Group Investigation (GI) Terhadap Kemampuan Berpikir Kritis Matematika Siswa Kelas V MIN 15 Bintaro [The Influence of Group Investigation (GI) Learning Model on Mathematics Critical Thinking Ability of Fifth Grade Students MIN 15 Bintaro]. Skripsi. Fakultas Ilmu Tarbiyah dan Keguruan. UIN Syarif Hidayatullah Jakarta

Hartono, D. P. (2014). Pengaruh Model Pembelajaran Investigasi Kelompok Terhadap Hasil Belajar Mahasiswa Universitas Negeri Malang [The Effect of Group Investigation Learning Model on Student Learning Outcomes of State University of Malang]. Malang: Program Pascasarjana Universitas Negeri Malang.

Juniartina, P. P (2015). Pengaruh Model Pembelajaran Kooperatif Group Investigation Terhadap Pemahaman Konsep Dajn Kemampuan Berpikir Kritis Siswa [The Influence of the Group Investigation Cooperative Learning Model on Concept Understanding Dajn Students' Critical Thinking Ability]. Jurnal FMIPA UNDIKSHA $V$

Kusmanto, H. (2014). Pengaruh Berpikir Kritis Terhadap Kemampuan Siswa Dalam Memecahkan Masalah Matematika [The Effect of Critical Thinking on Students' Ability to Solve Mathematical Problems]. Jurnal EduMa, 3(1).

Maharani, S. (2017). Pengaruh Model Pembelajaran Group Investigation Terhadap Prestasi Belajar Trigonometri Mahasiswa [The Effect of Group Investigation Learning Model on Student Trigonometry Learning Achievement]. Jurnal Math Educator Nusantara (JMEN), 03(01).

Mirnawati, L. B. (2017). Pengaruh Model Pembelajaran Kooperatif Tipe Group Investigation Terhadap Kreativitas Mahasiswa Semester I PGSD UM Surabaya pada Mata Kuliah Pengantar Manajemen Pendidikan [The Influence of the Group Investigation Type of Cooperative Learning Model on the Creativity of the First Semester Students of PGSD UM Surabaya in the Introduction to Education Management Course]. Pedagogia: Jurnal Pendidikan, 6(1), 84-97. https://doi.org/10.21070/pedagogia.v6i1.598

Mushoddik, S. U. (2016). Pengaruh Model Pembelajaran Group Investigation Terhadap Kemampuan Berpikir Kritis Siswa SMA MAN 6 Jakarta [The Influence of Group Investigation Learning Model on Critical Thinking Ability of SMA 6 MAN 6 Jakarta Students]. Jurnal Geo Edukasi, Vol 5 (2): 1-10 
Mushoddik, Utaya, S., \& Budijanto. (2016). Pengaruh Model Pembelaaran Group Investigation Terhadap Kemampuan Berpikir Kritis Siswa MAN 6 Jakarta [The Influence of the Group Investigation Learning Model on the Critical Thinking Ability of MAN 6 Jakarta Students]. Swarnabhumi, 1(1), 1-10. http://jurnalnasional.ump.ac.id/index.php/GeoEdukasi/index

Ngalimun. (2012). Strategi dan Model Pembelajaran [Learning Strategies and Models]. Yogyakarta: Aswaja Pessindo.

Nuryatin, A. (2015). Pengaruh Model Pembelajaran Kooperatif Tipe Group Investigation Terhadap Kemampuan Berfikir Kritis [The Influence of the Group Investigation Type of Cooperative Learning Model on Critical Thinking Ability]. Angewandte Chemie International Edition, 6(11), 951952

Nurhayati. (2014). Peningkatan Kemampuan Berfikir Kritis siswa Dalam Pembelajaran IPS Melalui Pendekatan SAVI Model Pembelajaran Berbasis Masalah Kelas VII SMP Negeri Godeon [Improving Students' Critical Thinking Ability in Social Studies Learning Through the SAVI Approach Problem-Based Learning Model for Class VII SMP Negeri Godeon]. Skripsi. Jurusan Pendidikan Ilmu Pengetahuan Sosial Fakultas Ilmu Sosial. Universitas Negeri Yogyakarta.

Slavin, R. E. (2010). Cooperative Learning Teori, Riset, dan Praktik [Cooperative Learning Theory, Research, and Practice]. Bandung: Nusa Media.

Sugiarti, S. A. A. (2012.) Pengaruh Penerapan Model Pembelajaran Kooperatif GI Terhadap Pemahaman Konsep Kimia Dan Kemampuan Berpikir Kreatif Siswa SMAN 3 Denpasar [The Influence of the Application of the GI Cooperative Learning Model on the Understanding of Chemical Concepts and Creative Thinking Ability of SMAN 3 Denpasar Students].

Sugiyono. (2017). Metode Penelitian Pendidikan (Pendekatan Kuantitatif, Kualitatif dan R\&D) [Educational Research Methods (Quantitative, Qualitative and $R \& D$ Approaches)]. Bandung: Alfabeta.

Sumarmi. (2012). Model-Model Pembelajaran Geografi [Geography Learning Models]. Malang: Aditya Media.

Suprijono, A. (2009). Cooperative Learning Teori Dan Aplikasi PAIKEM [PAIKEM Co Cooperative Learning Theory and Applications]. Surabaya: Pustaka Pelajar

Wuryani. (2017). Peningkatan Hasil Belajar IPA dengan Model Kooperatif Tipe Group Investigation Pada Siswa Kelas V SD [Improving Science Learning 
Outcomes with Cooperative Models of Group Investigation Type for Fifth Grade Elementary School Students]. E-Jurnal Mitra Pendidikan, 1(5). 